\title{
Uzroci poteškoća u mirovinskom sustavu i razlozi zašto treba očuvati kapitalizirano mirovinsko osiguranje u Hrvatskoj
}

PREDRAG BEJAKOVIĆ *

Institut za javne financije

Zagreb, Hrvatska
Pregledni rad

UDK: 369.5:36(497.5)

doi: 10.3935/rsp.v26i1.1575

Primljeno: srpanj 2018.

»U društvu je potrebno ostvariti pošteni odnos između onih kojih više nema, nas danas i onih koji će doći iza nas.« Edmund Burke (1729. - 1797.)

Mirovinski sustav ima različite zadaće koje su ponekad i međusobno suprotstavljene. Usprkos očitom poboljšanju materijalnog položaja starijih osoba, sustav međugeneracijske solidarnosti ima i neke neželjene učinke - izobličuje ponudu rada i oblike naknade, povećava gubitke mrtvog tereta doprinosa, uvjetuje pretjeranu preraspodjelu i stvara dugoročno neodrživ pritisak na javne financije. Stoga je u Hrvatskoj provedena mirovinska reforma i uveden sustav osobnih računa. Njegovo moguće zamrzavanje ili ukidanje imalo bi vrlo nepovoljne gospodarske učinke, a dovelo bi i do razbijanja povjerenja u taj sustav štednje. Ono bi samo nakratko ublažilo proračunski deficit, a državi bi stvorilo velike dugotrajne poteškoće u ispunjavanju obveza prema osobama koje su ostvarile mirovinska prava. Cilj ovog rada je pojasniti važnost očuvanja obveznog kapitaliziranog mirovinskog osiguranja (drugog stupa) u Hrvatskoj. U radu se pojašnjavaju njegova najznačajnija obilježja te navode mogućnosti poboljšanja i unapređenja.

Ključne riječi: mirovinski sustav, mirovinska prava, kapitalizirano mirovinsko osiguranje, socijalna sigurnost, Hrvatska.

\section{UVODNE NAPOMENE}

Mirovinski sustav ima različite, vrlo zahtjevne i složene, zadaće. To je prije svega način osiguranja stanovnika koji uplaćuju sredstva (doprinose za mirovinsko osiguranje) tijekom radnog vijeka kako bi u trenutku umirovljenja imali pravo na primanje mjesečnih mirovina kako ne bi bili siromašni. Sustav također pruža naknade onesposobljenim radnicima, odnosno ovisnim i preživjelim članovima obitelji umirovljenih i onesposobljenih radnika. Nadalje, time se želi postići ravnomjerna raspodjela dohotka pojedinaca i obitelji tijekom cijelog životnog vijeka, kao i poticanje pojedinačne i nacionalne štednje. Konačno, mirovinski sustav ostvaruje i preraspodjelu između onih koji su imali veće dohotke i plaćali veće doprinose i osoba koje su imale manje dohotke i/ili kraći radni staž, pa su slijedom toga i platile manje doprinosa. Jedan od najvaž-

\footnotetext{
* Predrag Bejaković, Institut za javne financije / Institute of Public Finance, Smičiklasova 21, 10000 Zagreb, Hrvatska / Croatia, predrag@ijf.hr
} 
nijih ciljeva mirovinskog osiguranja jest održavanje dohotka starijih osoba i čini se kako je tu program bio poprilično uspješan. Dok su starije osobe nekad mnogo češće pripadale relativno siromašnima, današnji pokazatelji upućuju na prilično pozitivne učinke (Barr, 2000.). Ne samo da je stopa siromaštva starijih pala (Pan, 2011.; OECD, 2016.), nego je u većini zemalja - uključujući i Hrvatsku - obično ispod ili vrlo blizu stope siromaštva ukupnog stanovništva (Bejaković, 2013.). Zahvaljujući mirovinama i drugim socijalnim transferima, stopa smanjivanja rizika od siromaštva u Hrvatskoj slična je prosjeku za zemlje EU-25 i nešto niža nego za zemlje EU-10. Ako se starosne i obiteljske mirovine uključe u dohodak, onda je stopa smanjivanja rizika od siromaštva u Hrvatskoj zahvaljujući socijalnim transferima veća nego u EU-25 (Ministarstvo zdravstva i socijalne skrbi, 2007.). Stopa rizika od siromaštva prije socijalnih transfera (mirovine uključene u dohodak) u 2005. godini iznosila je 34,9\%, a nakon transfera bila je $17,5 \%$. Stopa rizika od siromaštva prije socijalnih transfera (mirovine uključene u dohodak) za 2016. godinu iznosila je 44,9\%, a nakon $19,9 \%$ (Državni zavod za statistiku, 2017.). Šućur (2005.) navodi kako se, na primjeru 2003. godine, značajnije poboljšao financijski položaj umirovljenika (pad stope siromaštva za 2,5\%). Ipak, još uvijek znatan broj umirovljenika živi ispod praga siromaštva te oni čine oko trećine svih siromašnih.

Sve mirovinske reforme ustvari nastoje riješiti jedno pitanje: kako osigurati pristojan životni standard povećanom broju starijih građana bez istodobnog stvaranja pretjeranog financijskog tereta za javne financije. Pritom su postojali različiti pristupi koji su se kretali od parametrijskih reformi u tradicionalnim javnim sustavima tekuće međugeneracijske solidarnosti (Pay-As-You-Go ili PAYG) do uvođenja novih mirovinskih formula (kao što su notional funding) u PAYG sustave pa sve do razvoja kapitali- ziranih privatnih mirovinskih osiguranja. Šrina i obilježja reforme te posebnosti u promjenama bile su jako različite od zemlje do zemlje što je u najvećoj mjeri odražavalo nacionalne tradicije, probleme i prioritete.

Cilj ovog rada je ukazati na važnost očuvanja obveznog kapitaliziranog mirovinskog osiguranja (drugog stupa) u Hrvatskoj. Nakon uvodnih napomena slijedi dionica o pregledu literature. U trećem dijelu objašnjavaju se obilježja mirovinskog osiguranja međugeneracijske solidarnosti te uzroci i posljedice problema koje su u njemu nastale. Cetvrti dio rada posvećen je razlozima uvođenja drugog stupa kapitaliziranog privatnog mirovinskog osiguranja. Tu se pobliže objašnjava mirovinska reforma, kritike koje su njoj upućene te se raspravlja o njihovoj opravdanosti. U petom, zaključnom, poglavlju sadržane su među ostalim i opasnosti od nedovoljno promišljenih mjera zamrzavanja i ukidanja drugog stupa mirovinskog osiguranja.

\section{PREGLED LITERATURE S OSVRTOM NA NEDOSTATKE SUSTAVA MEĐUGENERACIJSKE SOLIDARNOSTI}

Opsežnija i podrobnija istraživanja sustava i reformi mirovinskog osiguranja započela su sredinom 1970-ih (Feldstein, 1995. a, b, c, d). Središnji pojam u razmatranju mirovinskog osiguranja bila je »imovina mirovinskog osiguranja«, koja se može definirati kao sadašnja stvarna vrijednost prava u sustavu mirovinskog osiguranja koju će ostvarivati sada odraslo stanovništvo kada navrši 65 godina života (ili ga već ostvaruje ako je starije od 65 godina) umanjena za sadašnju stvarnu vrijednost doprinosa za sustav mirovinskog osiguranja koji će biti izdvojeni prije dostizanja te dobi. Prema Feldsteinu (1996.), imovina mirovinskog osiguranja u SAD-u sredinom 1990-ih narasla je na više od 1,5 puta BDP-a. Kako imovina mirovinskog osiguranja za svaku 
odraslu osobu u zemlji iznosi više od 50 tisuća američkih dolara, vrijednost ukupnog bogatstva mirovinskog osiguranja znatno je veća od bilo koje druge imovine većine američkih kućanstava. Ukupno uzevši, imovina mirovinskog osiguranja veća je od tri četvrtine uobičajeno mjerene cjelokupne privatne imovine (Rosen, 1999.).

Ustvari, imovina mirovinskog osiguranja nije prava imovina, nego samo pravo sadašnjih i budućih osoba koje plaćaju doprinose. Kao uobičajeni javni dug, imovina mirovinskog osiguranja je prikriveni (implicitni) javni dug koji je tri puta veći nego službeni nacionalni (eksplicitni) dug (Rosen, 1999.; Organisation for Economic Co-operation and Development, 2014.). Gledajući dalje u budućnost, ukupna prava u mirovinskom osiguranju rast će kako se povećava stanovništvo, kako ono postaje relativno starije i kako raste dohodak. Financijske teškoće sustava obveznog solidarnog javnog mirovinskog osiguranja stoga su vrlo ozbiljne. Stoga je nužno barem najkraće razmotriti nastale gubitke uslijed mrtvog tereta koji uzrokuje izobličenja ponude rada. Nakon toga važno je istražiti gubitke u blagostanju u određenom vremenskom razdoblju uzrokovane smanjenom akumulacijom kapitala.

Doprinosi nekapitaliziranom mirovinskom sustavu koji se obračunavaju na plaće iskrivljuju ponudu rada i vrste (oblike) naknade. Iako veza između doprinosa mirovinskog sustava koje pojedinci plaćaju i prava koja na temelju toga ostvaruju podrazumijeva da obvezne zakonske stope doprinosa uvećavaju stvarne granične porezne stope koje terete pojedinca, doprinosi mirovinskom osiguranju su ustvari stvarni porezi sa značajnim dijelom gubitaka uslijed mrtvog tereta doprinosa. Ti gubici su neminovni zbog slabog povrata koji je posljedica sustava isplate mirovina iz tekućih prikupljenih sredstava (PAYG). Za razliku od privatnih mirovinskih fondova i miro- vinskih osobnih računa građana (kapitalizirani sustav), nekapitalizirani sustav mirovinskog osiguranja ne ulaže prikupljeni novac u obveznice i vrijednosne papire, već $\mathrm{u}$ istoj godini prikupljena sredstva isplaćuje u obliku mirovina i ostalih prava. Stopa povrata koju pojedinac može ostvariti obveznim doprinosima u sustavu općeg mirovinskog osiguranja stoga je puno niža od one koja se može dobiti u privatnim mirovinskim fondovima i mirovinskom osiguranju s neposrednim financiranjem.

Feldstein (1996.) procjenjuje kako nekapitalizirani sustav mirovinskog osiguranja sa stalnim stopama doprinosa omogućava pozitivni povrat koji u ravnoteži odgovara stopi povećanja obračunske osnovice doprinosa, koji je u SAD-u u razdoblju 1960. 1995. iznosio oko 2,6\%. Za razliku od toga, realna bruto dobit nefinancijskog korporacijskog kapitala u istom 35-godišnjem razdoblju iznosila je u prosjeku 9,3\% godišnje. To je povrat koji bi svaki pojedinačni osobni račun u mirovinskom osiguranju mogao ostvariti da sredstva nisu utrošena u javnom mirovinskom osiguranju. Tako su obvezni doprinosi nekapitaliziranom sustavu mirovinskog osiguranja ustvari porezi koji imaju značajne gubitke uslijed mrtvog tereta. To je ustvari gubitak blagostanja koji nastaje uvođenjem neke novčane obveze - poreza ili doprinosa, a koji ne pripada nikome, niti onome tko plaća, niti onome tko koristi, a niti državi. Drugim riječima, mrtvi teret izražava mjeru neefikasnosti koju uvjetuju porezi.

Možemo zamisliti zaposlenu osobu koja plaća 1000 novčanih jedinica doprinosa mirovinskom osiguranju za ostvarivanje mirovine na koju će imati pravo kada navrši 75 godina. S 2,6\% prinosom tih će 1000 jedinica narasti nakon 25 godina na 1900 jedinica. Za razliku, prinos od 9,3 posto omogućio bi pojedincu da ostvari istu mirovinu od 1900 dolara ako bi platio samo 206 novčanih jedinica. Stoga, ako se gra- 
đane prisiljava da koriste nekapitalizirani sustav mirovinskog osiguranja, dramatično se povećavaju njihovi troškovi stjecanja mirovina. U navedenom primjeru, kapitalizirani sustav omogućio bi pojedincu da ostvari pravo na mirovinu uz samo $21 \%$ cijene koju inače mora platiti u nekapitaliziranom sustavu mirovinskog osiguranja čime bi se omogućilo da se 12 postotni doprinos nekapitaliziranog sustava mirovinskog osiguranja zamijeni 2,5 postotnim doprinosom za nekapitalizirani sustav. Preostalih 9,5\% obveznog doprinosa ustvari je porez za koji uplatitelj ne dobiva gotovo ništa za uzvrat.

Gubici mrtvog tereta doprinosa mogu biti znatno veći nego što se obično misli. Doprinosi iskrivljuju ne samo broj sati koje pojedinac radi, nego isto tako i ostala obilježja ponude rada poput izbora zanimanja, mjesta rada i radnih napora. Oni također iskrivljuju oblike i načine naknada za rad, prelazeći s novčanih primanja koja se oporezuju na dodatne materijalne pogodnosti koje tvrtke osiguravaju svojim zaposlenima (poput plaćenih ljetovanja, zimovanja, korištenja službenog automobila i drugo), bolje uvjete rada i slično. Ova iskrivljenja u oblicima i načinima naknada zapravo su iskrivljenja obrazaca potrošnje pojedinca. Feldstein (1995.b) je jasno pokazao kako su gubici mrtvog tereta poreza uzrokovani cijelim nizom iskrivljenja (broja radnih sati, šireg oblika ponude rada i obrazaca potrošnje), određeni oblicima i načinima naknada za rad i korištenjem poreznih umanjenja. Taj gubitak mrtvog tereta u SAD-u iznosi oko $1 \%$ BDP-a i približno petinu ukupnih prihoda mirovinskog sustava.

Dodatni gubici mrtvog tereta koji su posljedica tih vrlo nepovoljnih veza većih doprinosa i većih prava bili bi automatski ukinuti u privatnom kapitaliziranom sustavu mirovinskog osiguranja u kojem bi svatko imao svoj račun. Naravno, ti bi se gubici mogli ukinuti i u postojećem nekapitaliziranom općem sustavu mirovinskog osiguranja ako bi svaki osiguranik imao svoj osobni račun na kojem su evidentirani njegovi doprinosi. Feldstein (1996.) zaključuje kako se izobličenja ponude rada i nastali gubici mrtvog tereta koji su posljedica niske stope dobiti (povrata) u nekapitaliziranom sustavu mirovinskog osiguranja ne mogu ukloniti bez prelaska na opći kapitalizirani sustav osiguranja u kojem bi se neposredno uplaćivalo, ili privatni sustav mirovinskog osiguranja u kojem bi svatko imao svoj osobni račun za ostvarenja mirovine.

Gubitak zbog mrtvog tereta doprinosa koji nastaje uslijed izobličenja ponude rada nije jedina loša posljedica nekapitaliziranog sustava mirovinskog osiguranja, pa čak niti najgora. Čak i kada ne bi bilo izobličenja ponude rada ili u načinima kompenzacije (odnosno kada bi elastičnost nadoknade obračunske osnovice - porezne osnovice - u odnosu na neto poreznu stopu (stopu doprinosa) bila jednaka nuli); svaka generacija nakon početne (prve u vrijeme osnivanja sustava) gubila bi jer bi bila prisiljena sudjelovati u općem sustavu solidarnog osiguranja koji ima malu stopu dobiti/povrata. U kojoj će mjeri nekapitalizirani sustav mirovinskog osiguranja uzrokovati smanjenje nacionalne dobiti od kapitala i pogoršanje ekonomskog blagostanje ovisi o tome kako ce se ponašati pojedinačne štednje u odnosu na doprinose mirovinskog osiguranja i proistekla prava te što će vlada poduzimati u uvjetima smanjivanja privatne štednje (Rosen, 1999.).

Tako, na primjer, u SAD-u (a slično i u mnogim drugim zemljama) pojedinac koji je imao prosječna primanja kroz cijeli svoj radni vijek i koji odlazi u mirovinu u dobi od 65 godina te ima suprugu koja nije radila prima mirovinu koja odgovara iznosu $63 \%$ njegovih primanja tijekom pune godine prije umirovljenja. Kako mirovina tog pojedinca ne podliježe oporezivanju, ona ustvari iznosi više od 80 posto njegovog najvišeg neto dohotka prije oporezivanja. 
Zdrav razum i svakodnevno iskustvo kažu da će osobe koji očekuju tako visok stupanj zamjene dohotka vrlo malo štedjeti za mirovinu. Ako nešto i štede u godinama prije mirovine, to je vjerojatno iz poreza kako bi ublažili neočekivane promjene u dohotku ili potrošnji. Nimalo ne iznenađuje da su razine štednje u velikom broju zemalja ustvari vrlo male. Stoga u SAD-u, čak iako se gleda šire od same financijske imovine, medijalna neto vrijednost imovine (uključujući i vrijednost kuće) među svim kućanstvima ispod 65 godina starosti iznosila je krajem 20. stoljeća svega 28 tisuća dolara (Rosen, 1999.).

Većina teoretičara (Barr, 2000.; Holzmann and Hinz, 2005.; International Federation of Pension Fund Administrators - FIAP, 2016.) slaže se kako bi prijelaz na sustav neposrednih računa smanjio mrtve terete koji uzrokuju da doprinosi za mirovinsko osiguranje izobličuju (iskrivljenu) ponudu rada. Podsjetimo da je to smanjivanje gubitka zbog mrtvog tereta pojava koja se ne može postići preraspodjelom postojećeg implicitnog povrata, već ovisi o povećanju stope povrata na doprinose mirovinskog osiguranja od stope rasta nadnica na realni povrat od kapitala. Kako privatizacija trajno smanjuje gubitke zbog mrtvog tereta i daje pojedincima (nakon prve generacije) priliku da ostvare veće povrate na svoje obvezne mirovinske uštede, moguće je oblikovati prelazak na sustav neposrednih računa koji stavlja svaku generaciju u bolji položaj nego što ona ima u sadašnjem sustavu. To se može učiniti korištenjem dodatnog duga za ublažavanje troškova prelaska kroz razdoblje duže od jedne generacije.

Doprinosi na plaće u sadašnjem općem sustavu solidarnosti izobličuju ponudu rada i oblike naknade, povećavaju gubitke mrtvog tereta osobnih doprinosa i poreza za $50 \%$. Dodatno, svaka generacija sada i u budućnosti gubi na razlici između povrata na realni kapital koji bi se ostvario u su- stavu neposrednih računa i mnogo nižeg povrata koji se ostvaruje u općem sustavu solidarnosti. Iduća dionica posvećena je mirovinskom osiguranju međugeneracijske solidarnosti u Hrvatskoj.

\section{MIROVINSKO OSIGURANJE MEĐUGENERACIJSKE SOLIDARNOSTI U HRVATSKOJ}

Mirovinski sustav međugeneracijske solidarnosti (u Hrvatskoj prvi stup) znači da se sadašnje mirovine isplaćuju iz tekućih doprinosa koje uplaćuju sadašnji obveznici uplate doprinosa. Kako početna generacija prima mirovine jednake početnom iznosu doprinosa, prihvaćanje općeg sustava solidarnosti umjesto kapitaliziranog sustava neposrednih računa uzrokuje gubitak neto sadašnje vrijednosti ako je razlika u povratu po novčanoj jedinici neostvarenih investicija veća od diskontne stope prilagođene rastu. Pritom dolazi do međugeneracijske preraspodjele, odnosno starije generacije (umirovljene prvih 30-ak godina od uvođenja sveobuhvatnog mirovinskog sustava) ostvaruju pozitivan transfer jer su plaćale doprinose po relativno nižim stopama, a primaju mirovine što se financiraju po mnogo većim stopama doprinosa koje terete sada zaposlene (Zuber, 2010.). Sadašnje (i buduće) generacije ostvaruju negativan životni transfer jer plaćaju visoke mirovinske doprinose, a ostvaruju nižu razinu mirovina od prijašnjih generacija (razina mirovina $u$ odnosu na plaće). Ta međugeneracijska preraspodjela nastavit će se i ubuduće najviše zbog demografskih razloga: sve malobrojnije mlađe generacije financirat će mirovine relativno velikog broja umirovljenika te će biti sve nepovoljniji odnos između doprinosa i mirovina s obzirom na prethodne naraštaje (Nestić i Tomić, 2012.).

Postoji ujedno i unutargeneracijska preraspodjela u kojoj se istražuje koliko su bogatiji kroz mirovinske doprinose dali za siromašnije; u zemljama koje imaju dugo 
godina mirovinsko osiguranje, za nedavno umirovljene i za one koji će u budućnosti odlaziti u mirovinu općenito vrijedi načelo: što su primanja i mirovinski doprinosi veći, manji je dobitak od mirovinskog osiguranja. Razlog je što većinom ne postoji utvrđena najniža i najviša plaća, a određena je najniža mirovina - mirovina na koju osiguranik ima pravo ako mu je prosječna plaća na temelju koje su izračunati njegovi prosječni vrijednosni bodovi bila niža od prosječne plaće (Urban, Munđar, Bejaković, 2011.). S druge strane, postoji najviša mirovina što je najviša svota do koje se može odrediti mirovina (prema plaći osiguranika) koja se ostvaruje prema općim propisima o mirovinskom osiguranju.

Temeljno obilježje svakog mirovinskog sustava je preraspodjela od onih koji umiru ranije na one koji žive duže. Očekivano trajanje života povezano je s rodom i društvenim statusom: žene žive dulje od muškaraca, menadžeri žive dulje od radnika, a bolje obrazovani i bolje plaćeni ljudi žive duže od slabije obrazovanih i manje plaćenih. Tako se ostvaruje unutargeneracijska preraspodjela od muškaraca prema ženama, od radnika prema menadžerima i od siromašnih prema bogatima. Mirovinski sustavi se često koriste za ublažavanje različitih ekonomskih utjecaja čime se pojačava preraspodjela preko i iznad ekonomske racionalnosti i socijalne dopustivosti. Snažno i sve veće obilježje preraspodjele mirovinskih sustava potiče bolje plaćene skupine osiguranika na izbjegavanje plaćanja doprinosa, slabije plaćene na prijevremeno povlačenje iz svijeta rada, a jedne i druge na nedovoljne radne napore.

U Hrvatskoj je do 2002. godine postojao samo javni mirovinski sustav međugeneracijske solidarnosti. Zato su se rashodi za tekuće mirovine uglavnom financirali iz uplaćenih doprinosa zaposlenika. Takav je mirovinski sustav dospio u duboku krizu jer se iz postojećih uplaćenih doprinosa nisu mogli financirati umirovljenici. Tako su nastali manjkovi financirani transferima iz državnog proračuna ili zaduživanjem države na domaćem, odnosno inozemnom financijskom tržištu.

$\mathrm{Na}$ to su utjecali mnogobrojni čimbenici: nepovoljan odnos između broja osiguranika i umirovljenika, velik broj umirovljenika koji pojedinačno primaju male mirovine s tendencijom njihovog daljnjeg smanjivanja, visoka izdvajanja za mirovinsko osiguranje, rani odlazak u mirovinu uz razmjerno kratak staž osiguranja, povećanje očekivanog trajanja života, dugotrajno korištenje mirovinskih prava. Građani uglavnom ne štede za mirovinu i imaju velika očekivanja od države. Ako visina mirovine slabo ovisi o uplaćenim doprinosima, osiguranici će nastojati ne plaćati doprinose i/ ili odlaziti ranije u mirovinu nego što bi to inače činili. To je pogotovo istina ako plaćanje doprinosa nije uvjet za ostvarivanje mirovinskih prava.

Javni mirovinski sustav zbog starenja stanovništva (većeg udjela starijeg stanovništva uslijed povećanja očekivanog trajanja života što je jedno od najvećih civilizacijskih uspjeha društva i sve manjeg broja novorođenih) te navedene slabe povezanosti uplaćenih doprinosa i visine mirovine nužno je zahtijevao velike transfere iz proračuna središnje države. Tek se nešto više od polovice ukupnih mirovinskih rashoda pokriva prihodima od doprinosa te je taj sustav postao jedan od najznačajnijih uzročnika ozbiljnog fiskalnog deficita. Prema podacima Hrvatskog zavoda za mirovinsko osiguranje (2018., Tablica 19.c), u Hrvatskoj je u 2018. prosječna dob novih korisnika mirovina koji su ostvarili pravo na starosnu mirovinu iznosila 62 godine i 6 mjeseci, i to 63 godine i 5 mjeseci za muškarce i 60 godina i 11 mjeseci za žene. Kod osoba koje primaju invalidsku mirovinu to je osjetno niže i iznosi 53 godine i 6 mjeseci, 54 godine i 6 mjeseci za muškarce i 51 
godinu i 2 mjeseca za žene. Novi korisnici imaju manje od 32 godine radnog staža. Zahvaljujući zavidnom očekivanom trajanju života (u 2014. žene 80,5 godina, muškarci gotovo 74,6), korisnici mogu očekivati da će razmjerno dugo primati mirovinu (žene više od 23 godine, a muškarci gotovo 19). Sve navedeno utjecalo je na velika financijska izdvajanja za mirovinski sustav i značajne javne rashode pa se zbog toga pristupilo mirovinskoj reformi, čemu je posvećena idući dio rada.

\section{MIROVINSKA REFORMA U HRVATSKOJ I NJEZINE KRITIKE}

Osim svih drugih promjena $\mathrm{u}$ javnom mirovinskom sustavu, u cilju ublažavanja njegovih nedostataka u drugoj polovici 1990-ih, Hrvatska je uvela osobne mirovinske račune u privatnom sustavu kapitaliziranog osiguranja definiranih doprinosa koji je zaživio 2002. (Vukorepa, 2011.; Zuber, 2010.). Drugi (obvezni) stup temelji se na individualnoj kapitaliziranoj štednji dijela mirovinskih doprinosa. Zatečeni osiguranici, mlađi od 40 godina, odnosno oni između 40 i 50 godina koji su se za to dobrovoljno opredijelili, dio svog doprinosa ulažu u drugi stup obvezne kapitalizirane štednje u mirovinskom fondu koji sami odaberu. Tri četvrtine doprinosa te kategorije osiguranika ide u prvi stup, a jedna četvrtina u drugi stup. Osiguranici koji su osigurani u drugom stupu ostvaruju dvije mirovine - iz prvoga i drugog stupa.

Najvažniji razlog uvođenja takvog oblika osiguranja bila je želja za diversifikacijom rizika, kako se sva sredstva, poput jaja ne bi držala u samo jednoj košari. Ujedno, željelo se potaknuti osiguranike na dulje ostajanje u svijetu rada i plaćanje doprinosa (odnosno smanjivanje izbjegavanja plaćanja) jer se sa sigurnošću može očekivati da će ljudi željeti raditi duže i u potpunosti plaćati mirovinske doprinose ako njihova mirovina izravno ovisi o uplaćenim doprinosima, što često nije slučaj u prvom stupu međugeneracijske solidarnosti (Bejaković, 2002.). Konačno, željeli su se ublažiti spomenuti nepovoljni učinci pretjerane preraspodjele koja obilježava sustav međugeneracijske solidarnosti (Potočnjak i Vukorepa, (2018.). Istina, uvođenje II. stupa mirovinskog osiguranja značilo je i određeni tranzicijski trošak reforme čiji iznos nije zanemariv. Na razini godine procijenjen je u iznosu od 5 milijardi kuna (1,5\% BDP-a) (Raiffeisen istraživanja, 2014.). Uslijed uplaćivanja dijela doprinosa u II. stup mirovinskog osiguranja, dolazi do pojačanog manjka u prvom stupu međugeneracijske solidarnosti za koji je odlučeno da će biti pokriven iz državnog proračuna.

Moguće kritike na kapitalizirano mirovinsko osiguranje obično se vezane uz ideološku nesklonost prema privatizaciji socijalnih prava kao što je mirovinsko osiguranje i smanjenoj ulozi države u tome, visokom tranzicijskom trošku, slabom i/ili nesigurnom povratu te visokim naknadama mirovinskih društava.

Privatizacija socijalnih prava - kako je prva kritika možda najčešća, potrebno ju je podrobno razmotriti. Tu se ističe kako se važno pravo kao mirovinsko osiguranje ne smije prepustiti privatnoj inicijativi i tržištu. Ipak, postoji ozbiljna nejasnoća uz pojam »privatizirati« koji je dvosmislen i uzrokuje političke primjedbe u slučaju da to znači potpuno ukidanje odgovornosti države za dohodak starijih osoba. Koristi od kapitaliziranog sustava odnose se na akumulaciju kapitala i postojanje posebnih računa koji vezuju obvezne doprinose svakog pojedinca na mirovinu koja će uslijediti. Bit je privatizacije i u tome mogu li pojedinci nadzirati svoja ulaganja. U kapitaliziranom sustavu koji ne bi bio privatan, država bi trebala investirati u privatne dionice, obveznice i hipoteke (Zuber, 2010.). Postoje očiti razlozi zašto se ne želi da država ostvaruje 
velika ulaganja u pojedine privatne tvrtke. Iako bi upravni troškovi mogli biti veći kada pojedinci imaju nadzor nad svojim ulaganjima, većina investicijskih fondova smanjila je svoje troškove na manje od četvrtine postotka na sredstva uložena u vlastitu imovinu fonda, $i$ čak na još manje kada je riječ o sredstvima uloženim u obveznice (Vukorepa, 2011.; Potočnjak i Vukorepa, 2018.). Čak i u privatnom sustavu pojedinci su obično ograničeni pri izboru sredstava i/ili fondova u koja će ulagati, i morala bi se uspostaviti opća sigurnosna mreža da se zaštite pojedinci čije investicije nisu polučile odgovarajući iznos mirovinue.

Država i u privatiziranom kapitaliziranom mirovinskom osiguranju ima itekako veliko značenje i mnoge obveze. Müller (2002.) navodi klasične i dodatne funkcije države u obveznom privatnom sustavu. Prve uključuju (1) oblikovanje i provedbu novog mirovinskog sustava; (2) regulaciju, nadzor rada mirovinskih fondova, informiranje $i$ izvještavanje, (3) financiranje tranzicijskih troškova i (4) pružanje implicitnog »mirovinskog jamstva kao posljednjeg utočišta«. Druge dodatne zadaće koje država dobiva su (5) obavljanje klirinških (obračunskih) poslova, (6) sponzoriranje mirovinskih fondova i (7) pružanje invalidskih i obiteljskih mirovina. Ujedno, (8) bitni su i opći uvjeti u kojima država ima središnje mjesto u ostvarivanju makroekonomske i političke stabilnosti.

Müller (2002.) u spomenutom tekstu vrlo podrobno i argumentirano pojašnjava zadatke države. Država usvajanjem zakonskih odredbi o osnivanju privatnog mirovinskog osiguranja i izborom pojedinih rješenja utvrđuje pravila igre. Učinkovita regulacija i nadzor obveznog kapitaliziranog sustava su od presudne važnosti u ublažavanju različitih rizika. To se može učiniti ili kroz izdvojenu nadzornu agenciju ili kroz postojeće nadzorne ustanove u financijskom sektoru. U mirovinskom osiguranju država ima obvezu osigurati i/ili pomoći u pružanju nezavisnog informiranja i savjetovanja kako bi građani imali jasne spoznaje o svojim pravima i obvezama. Kako privatno obvezno mirovinsko osiguranje ne nastaje $\mathrm{u}$ zrakopraznom institucionalnom prostoru, preusmjeravanje dijela doprinosa na privatne fondove gotovo sigurno pogoršava financijski položaj postojećeg javnog sustava. Tranzicijski troškovi mogu utjecati ne samo na postojeće umirovljenike čije se mirovine nastavljaju financirati iz sustava javnog mirovinskog osiguranja, već i na druga područja javnih financija kao što su proračunski deficit i javni dug. Pretjerano oslanjanje na deficitarno financiranje može voditi do povećanja makroekonomskih rizika. Ako privatni osiguravatelji ne ostvare očekivane povrate i/ili osiguranici uplaćuju u kapitalizirano osiguranje kratko vrijeme razmjerno male iznose, država se obično obvezuje na odobravanje dodatnih sredstava starim osobama kako bi im se ublažila opasnost od siromaštva u starosti. Država u pogledu pete zadaće često organizira prikupljanje doprinosa za drugi mirovinski stup putem poreznih uprava ili zavoda za javno mirovinsko osiguranje. Ponekad je država izravni ili neizravni sponzor mirovinskih fondova. U više zemalja Latinske Amerike, banke u pretežitom vlasništvu države vode svoje mirovinske fondove, time da im se odobrava značajna tržišna komponenta. Nadalje, ne smije se zanemariti niti pružanje invalidskih i obiteljskih mirovina: u Južnoj Americi (osim u Meksiku) privatna mirovinska osiguravajuća društva pružaju invalidska i obiteljska osiguranja za što zaračunavaju dodatne premije. U europskim tranzicijskim zemljama i nakon što je započela mirovinska privatizacija ti su oblici osiguranja ponajviše zadržani u javnom sustavu. Konačno i najvažnije, gotovo da nije potrebno podsjećati na važnost općih uvjeta. Očito u nedostatku stabilnih makroekonomskih uvjeta, privatni mirovinski fondovi bit će u teškom položaju. Ako drža- 
va ne može osigurati makroekonomsku stabilnost, bit će ugroženi i privatni mirovinski fondovi. Ako je inflacija visoka, privatno mirovinsko osiguranje još je više izloženo gubitku vrijednosti nego što je javno osiguranje. Makroekonomska stabilnost nije sve i cjelokupni preduvjet uspješnom kapitalnom mirovinskom osiguranju, ali sve je ništa bez makroekonomske stabilnosti. Drugi problem su politički rizici koji se ne odnose samo na javno, već i na privatno mirovinsko osiguranje, kako to pokazuju iskustva više latinoameričkih zemalja. Taj je učinak pogotovo važan ako je većina imovine uložena u zemlji pa stoga osiguranici snose cjelokupni rizik domaće makroekonomske stabilnosti i političkih uvjeta. Najkraće, u privatizaciji mirovinskog sustava nisu bitne samo sposobnosti privatnog sektora jer su podjednako važne i mogućnosti države. Stoga možemo podsjetiti na izvanrednu misao Nicholasa Barra (2000.: 23): »Ako je država neučinkovita, u opasnosti je bilo koji mirovinski sustav«.

Visoki tranzicijski trošak - svim zemljama koje su usvojile kapitalizirani sustav zajednički je problem visoki tranzicijski trošak prijelaza sa sustava generacijske solidarnosti na sustave mirovinskih fondova kapitalizirane štednje. Procjenjuje se kako teret financiranja tranzicijskih troškova obuhvaća razdoblje od najmanje 30 godina, pa čak do 50 godina (World Bank, 2011.). U trenutku kad svi zaposleni ili dio zaposlenih počne uplaćivati doprinose za sustav kapitalizirane štednje, povećava se nedostatak novca u fondovima javnog mirovinskog osiguranja iz kojih se financiraju mirovine sadašnjih umirovljenika. Uz postojeći broj umirovljenika i razinu dostignutog gospodarskog razvoja, ove zemlje teško mogu bez dodatne financijske pomoći izdržati tranzicijski trošak mirovinske reforme (Vukorepa, 2011.). Unatoč velikim tranzicijskim troškovima, uvođenje sustava kapitaliziranih mirovina obično nije bilo praćeno po- većanjem stopa obveznih doprinosa, već je samo izmijenjena struktura obveznih doprinosa. Vlade navedenih zemalja smatrale su kako bi povećanje stopa obveznih doprinosa, zbog njihova utjecaja na cijenu rada, destimuliralo ulagače $\mathrm{i}$ investitore. Sve su te zemlje bile prisiljene paralelno povećavati tržišnu konkurentnost svojih gospodarstava i rješavati problem financiranja tranzicijskog troška i sve su se opredijelile da nedostajuća sredstva potrebna za isplatu tekućih mirovina, nadoknade iz poreznih prihoda, odnosno troškove prevalile na porezne obveznike (Zuber, 2010.).

Ipak, potrebno je podsjetiti kako navedeni tranzicijski trošak predstavlja vidljivu stranu dotad nevidljivog implicitnog socijalnog duga (eng. implicit social security $d e b t$ ). To je neizravan dug koji imaju javni mirovinski sustavi prema umirovljenicima i radnicima koji su ostvarili ili će ostvariti mirovinska prava u sustavu socijalnog osiguranja. Vrijednost takvog neizravnog duga ovisi o broju obuhvaćenih radnika i umirovljenika, njihovoj dobi i očekivanom trajanju života, visini prosječnog davanja za mirovinu, godinama života za umirovljenje te diskontne stope koja se koristi kod izračunavanje sadašnje vrijednosti duga (Vukorepa, 2011.).

Slab i/ili nesigurni povrat je podjednako omiljena kritika kapitaliziranog mirovinskog osiguranja. Fultz (2011.) smatra kako je uvođenjem takvog osiguranja došlo do svojevrsnog kružnog kretanja: država najprije prikupi doprinose, onda ih usmjerava u privatne fondove, a nakon toga fond menadžeri ih vraćaju državi za kupnju obveznica. Dakle, država prikuplja sredstva, daje ga mirovinskim fondovima, a oni kupuju državne obveznice i zapravo vraćaju državi ta sredstva.

Odgovor ipak nije tako jednostavan. Štimac (2011.) podsjeća kako su mirovinski fondovi prema važećim zakonskim odredbama morali ulagati $50 \%$ u državne obve- 
znice. Prema Strategiji razvitka mirovinskog sustava i sustava socijalne skrbi (NN, 97/2003.), mirovinski fondovi kao i mirovinska osiguravajuća društva će najveći dio svoje imovine morati ulagati u državne vrijednosne papire (Vlada RH, 2003.). Zakon ih je na to prisilio kako bi država mogla financirati tranzicijski trošak (Vukorepa, 2011.). Nadalje, država 2009. godine nije mogla izdati niti jednu obveznicu u inozemstvu, pa su hrvatski mirovinski fondovi sudjelovali na svim izdanjima obveznica. Mirovinski fondovi gotovo sigurno nikada neće imati $70 \%$ u dionicama i to je vjerojatno dobro. Vjerojatno bi dobar omjer bio 60ak posto $\mathrm{u}$ instrumentima fiksnog prinosa i 40 posto $u$ varijabilnim instrumentima i drugim klasama imovine (Vukorepa, 2011.).

Kod ulaganja imovine postoje prilično snažna zakonska ograničenja (Zakon o obveznim i dobrovoljnim i mirovinskim fondovima, NN, 19/2014., 93/2015.) jer država nastoji što je moguće više osigurati da kapitalizirani fondovi ostvaruju pristojne povrate. Naravno, značajniji pozitivni financijski povrati za osiguranike mogu se ostvariti ako se uplaćuje dovoljno dugo vremena jer male uplate u kratkom vremenu mogu samo polučiti i odgovarajuće male povrate. $\mathrm{Na}$ samom početku uvođenja mirovinske reforme 2002. godine optimistične prognoze govorile su o mogućim prinosima obveznih fondova od $2 \%$ iznad stope inflacije.

Danas, s vremenskim odmakom od više od 16 godina, možemo zaključiti kako su hrvatski obvezni mirovinski fondovi ostvarili daleko zavidnije rezultate, bez obzira na činjenicu da je tijekom promatranog razdoblja globalno i hrvatsko tržište kapitala pogodila najveća gospodarska kriza. Prema podacima Hanfe, ukupna neto imovina obveznih mirovinskih fondova krajem 2017. godine iznosila je 91,9 mlrd. kuna, što je oko $26 \%$ bruto domaćeg proizvoda i povećanje od 9,5\% u odnosu na završetak 2016. godine. Osim toga, anualizirani prosječni prinosi domaćih obveznih mirovinskih fondova od vremena osnivanja ostvareni su na razini gotovo $6 \%$ što pokazuje da se ispunjavaju najvažniji ciljevi mirovinske reforme pokrenute 2002. Sukladno zakonskoj definiciji, prosječni godišnji prinos je oko $3 \%$ iznad inflacije, ali i više od prinosa koji je postavljen kao poželjan u trenutnu ulaska u mirovinsku reformu, a to je navedenih $2 \%$ iznad inflacije (tablica 1.).

Najveće prinose ostvarili su mirovinski fondovi kategorije A, koji su ujedno i najri-

Tablica 1.

Prinosi mirovinskih fondova II. stupa (u \%)

2003. 2004. 2005. 2006. 2007. 2008. 2009. 2010. 2011. 2012. 2013. 2014. 2015. 2016. 2017. $\begin{gathered}\text { Prinos } \\ \text { od po- } \\ \text { četka } \\ \text { rada }\end{gathered}$

Prinos

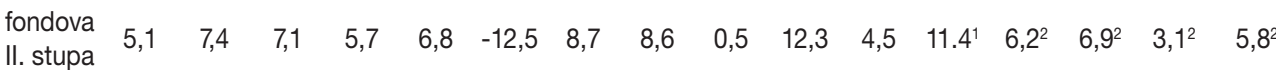

MIREX

${ }^{1}$ Izvještaj Reifeissen fonda za 2014., dostupan na http://www.sabor.hr/izvjestaj-o-radu-obveznih-mirovinskih-fondova-koji.

${ }^{2}$ Mirex B, najveći broj osiguranika je u tom sustavu, za najrizičniji Mirex A godišnji prinos za 2015. iznosio je 9,2\%, a za Mirex C 6,8\%. Prinos od početka rada za Mirex A iznosio je preko 10\%, a za Mirex $\mathrm{C}$ oko $7 \%$.

Izvor: www.hanfa.hr, Statistika. Za 2015. i prinos od početka rada Udruženje mirovinskih fondova (2016.). Izvještaj o radu obveznih mirovinskih fondova za 2015. godinu. Za 2016. i 2017. i prinos od početka rada Udruženje mirovinskih fondova (2018.). Izvještaj o radu obveznih mirovinskih fondova za 2017. godinu. 
zičniji, dok su najniže prinose ostvarili mirovinski fondovi umjerene rizičnosti, odnosno kategorije B. S obzirom da fondovi kategorija A i C posluju tek od kraja kolovoza 2014. godine, prerano je dati ocjenu ostvarenih prinosa obveznih mirovinskih fondova kroz duža razdoblja, tj. od njihovog osnutka. Obvezni mirovinski fondovi kategorije B slijednici su jedinstvenih obveznih mirovinskih fondova od prije vremena uvođenja kategorija $\mathrm{A}, \mathrm{B}$ i $\mathrm{C}$ te sukladno tome kategorija obveznih mirovinskih fondova u kojoj je daleko najviše članstva i imovine. Obvezni mirovinski fondovi kategorije B ulagali su oko $73 \%$ sredstava u domaće državne obveznice, te oko $25 \%$ u domaće i strane dionice. U ovoj kategoriji obveznih mirovinskih fondova maksimalno dozvoljena izloženost vlasničkim vrijednosnim papirima po zakonu iznosi 35\%. Razlog velikoj izloženosti obveznicama RH su važeća zakonska ograničenja ulaganja, ali i nepostojanje drugih kvalitetno pripremljenih projekata u koje bi mirovinski fondovi mogli ulagati sredstva, što sigurno nije greška tog oblika osiguranja niti mirovinskih fondova. Uz maksimalnu dozvoljenu izloženost vlasničkim vrijednosnim papirima od $35 \%$, ostatak portfelja od $65 \%$ moguće je razumno uložiti u domaće državne obveznice, jer instrumenti novčanih tržišta ne nude zadovoljavajuće prinose, kao ni obveznice drugih članica EU-a.

Prinosi hrvatskih mirovinskih fondova su među višima u regiji i Europi. Tako su, primjerice, njemački mirovinski fondovi tijekom 2010. godine ostvarili 4 do 5 postotni prinos, austrijski $6,6 \%$, a hrvatski $8,6 \%$ (Potočnjak i Vukorepa, 2018.). Uspjeh hrvatskih mirovinskih fondova posebno je pohvalan u usporedbi s učincima onih u zemljama srednje i istočne Europe. Njihov je prinos, istina, bio prilično mali u 2011., ali vrlo visok u 2012. pa je prosjek za te dvije godine bio zavidnih $6,4 \%$. Ako se uzme petogodišnje razdoblje 2008. - 2012., hrvatski obvezni mirovinski fondovi ostvarili su prosječni godišnji povrat od $3,5 \%$, što je među najvišim povratima u cijelom svijetu (OECD, 2016.; Udruženje mirovinskih fondova, 2016., 2018.). U posljednjem petogodišnjem razdoblju za koje su raspoloživi podaci (2011. - 2015.) prinos je iznosio 7,2\%. Prema podacima OECD-a (2016.: 18), od zemalja članica OECD-a najviše prosječne prinose u razdoblju u proteklih pet godina imali su (obvezni i dobrovoljni) mirovinski fondovi na Islandu (9,1\% nominalno i 5,7\% realno), Australiji (8,7\% i 6,2\%), Velikoj Britaniji (8,2\% i 6,1\%), Kanadi (8,0\% i 6,4\%) i Nizozemskoj (7,9\% i 6,1\%). Od zemalja koje nisu članice OECD-a najveće prosječne prinose u razdoblju u proteklih pet godina imali su Pakistan (16,2\% i 8,7\%), Urugvaj (14,6\% i 5,6\%) te Dominikanska Republika (11,6\% i 7,4\%).

Prema podacima OECD-a (2013.), u međunarodnoj usporedbi imovina hrvatskih mirovinskih fondova s oko 16,2\% BDP-a još uvijek je razmjerno mala, ali je potrebno podsjetiti i na kratko razdoblje postojanja tog oblika osiguranja u nas. Osjetno viši udio imaju Nizozemska (160,2\%), Island $(141,0 \%)$, Śvicarska $(113,6 \%)$ i Velika Britanija $(95,7 \%)$, a približno sličan imaju Poljska (17,2\%) i Novi Zeland (16,7\%). Veći broj razvijenih zemalja ima osjetno manji udio imovine mirovinskih fondova $\mathrm{u}$ BDP-u, kao, na primjer, Češka Republika $(7,1 \%)$, Njemačka $(6,3 \%)$, Italija $(5,6 \%)$, Koreja $(5,4 \%)$ i Austrija $(5,3 \%)$.

Pohvalno je da su provedene aktivnosti uvođenja tri različita potportfelja u obvezne mirovinske fondove. Time su mirovinski fondovi podijelili postojeći portfelj na tri dijela: konzervativan, srednji i dinamički portfelj (Vukorepa, 2015.). Mlađi članovi ušli su 2014. u dinamički portfelj, u srednjem portfelju osiguranici mogu biti do svoje 60., a svi, ako to žele, mogu biti u konzervativnom portfelju. Time se omogućava da mlađi naraštaji imaju višu stopu prinosa u doba kada mogu nositi rizik, odnosno kada još imaju dosta vremena za nadoknadu eventualnih gubitaka. Konačno, važno je postupno 
liberalizirati ulaganja mirovinskih fondova izvan Hrvatske.

Grbavac (2011.) ukazuje na veliku nepravdu u hrvatskom sustavu mirovinskog osiguranja. Prema Zakonu o dodatku na mirovine ostvarene prema Zakonu o mirovinskom osiguranju (NN, 79/2007.), pravo na dodatak na mirovinu od $27 \%$ imaju samo oni koji su osigurani u prvom stupu. Tako na taj dodatak nema pravo osiguranik i iz drugog stupa iako je na primjer $95 \%$ svojih ukupnih doprinosa tijekom radnog vijeka uplaćivao u sustav generacijske solidarnosti, a svega $5 \%$ u obvezni mirovinski fond. Zbog takve sistemske greške i nepravde nastaju velike razlike u mirovinama umirovljenika samo iz prvog stupa i onih koji su bili osigurani i u drugom.

Visina naknade - Fultz (2011.) naglašava visoke upravljačke naknade kao treću teškoću kapitalnog osiguranja. Česte se visoke naknade koje privatni fond menadžeri razrezuju osiguranicima za jednostavni čin kupnje državnih obveznica. Ne treba čuditi kako se postavlja pitanje: zašto platiti tako visoke upravljačke naknade? Vlade Poljske i Mađarske pokušale su smanjiti iznos naknada, ali u tome uglavnom nisu uspjele $\mathrm{i}$ postigle su tek skromne rezultate.

U Hrvatskoj postoji više oblika naknada mirovinskim fondovima kapitaliziranog osiguranja: 1) naknada od uplaćenih doprinosa, 2) naknada za upravljanje imovinom mirovinskog fonda, 3) naknada za izlaz člana iz fonda, 4) naknada za banku skrbnika i 5) naknada osiguravajućim mirovinskim društvima (Bađun i Klemenčić, 2011.; Zuber, 2010.). Naknada za Hanfu i naknada
Regosa sadržane su u prve tri naknade i plaćaju ih mirovinska društva. Prve tri naknade (radi pokrića troškova) može zaračunati obvezno mirovinsko društvo: odbitkom (do 2011. najviše $0,8 \%$ od uplaćenih doprinosa); odbitkom najviše $1,2 \%$ godišnje od ukupne imovine mirovinskog fonda u 2003.; za svaku iduću godinu Hanfa propisuje najviši postotak, ali ne viši od navedenog postotka; naplatom naknade za izlaz iz obveznog fonda, ukoliko se ne radi o izlasku nakon trogodišnjeg ulaganja u fond.

Hrvatski mirovinski fondovi svojim su članovima 2011. godine naplaćivali 0,8\% ulazne naknade na svaki uplaćeni doprinos i $0,65 \%$ godišnje naknade za upravljanje sredstvima (Bađun i Klemenčić, 2011.). Lako se uočava kako je naknada za upravljanje obveznom mirovinskom društvu stalno opadala u promatranom razdoblju od 2007. do 2012. i više je nego prepolovljena (tablica 2.). Cilj britanskih mirovinskih fondova je manje od $0,5 \%$ troška, u RH je već sada ispod $0,40 \%$ (bez Regosa 0,35\%, a dodatno bez Hanfe $0,31 \%$ ) jer razlika do naknade od $0,45 \%$ su sredstva koja mirovinski fondovi svake godine plaćaju Regosu od 30,00 HRK po članu (Obvezni mirovinski fond PBZ Croatia, 2018.; Udruženje mirovinskih fondova, 2016.). U pogledu strukture i visine naknade, najviše se smatra spornom upravljačka naknada jer se ubire uz ulaznu naknadu kao i dodatne troškove provizije, pristojbe vezane uz povećanje imovine mirovinskog fonda (Potočnjak i Vukorepa, 2018.). Njezin je utjecaj na razinu iznosa štednje znatan, pa tako upravljačka naknada od $0,5 \%$ smanjuje iznos ostvarene štednje kroz 40 godina za približno 10\% (Vukorepa, 2011.).

Tablica 2.

Visina maksimalne naknade za upravljanje obveznom mirovinskom društvu (u \%)

\begin{tabular}{|c|c|c|c|c|c|c|c|c|}
\hline Godina & 2007. & 2008. & 2009. & 2010. & 2011. -2012. & 2013. -2015. & 2016. & 2017. \\
\hline $\begin{array}{l}\text { Naknada (u \% od ukupne } \\
\text { imovine mirovinskog fonda) }\end{array}$ & 0,95 & 0,85 & 0,8 & 0,75 & 0,65 & 0,45 & 0,42 & 0,39 \\
\hline
\end{tabular}

Izvor: Odluka o najvišem postotku naknade za upravljanje obveznom mirovinskom društvu, NN 4/2007., 1/2008., 151/2008., 156/2009., 148/2010., 154/2011., 156/2013., čl. 63. st. 1. t. 2; Zakon o mirovinskim fondovima, NN, 19/2014., 93/2015.). 
Tako je u 2017. godini naknada za upravljanje u obveznom mirovinskom fondu iznosila $0,39 \%$ godišnje od osnovice, tj. od ukupne imovine fonda umanjene za obveze spram ulaganja, a za svaku daljnju godinu stopa naknade smanjuje za se $7 \%$. Stoga naknada za upravljanje OMF-ova za 2018. godinu iznosi $0,363 \%$ od osnovice. Naknada za upravljanje smanjivala se tijekom godina kako je rasla imovina OMF-ova (Obvezni mirovinski fond PBZ Croatia, 2018.). Usprkos povremenim kritikama u medijima, naknade hrvatskih mirovinskih fondova spadaju među niže u svijetu. U Poljskoj se, prema podacima OECD-a (2016.), naplaćuje ukupna naknada od 0,51\%, u Slovačkoj 0,94\%, u Estoniji 1,82\% ukupnih ulaganja. Među zemljama koje nisu članice OECD-a najviše naknade su u Albaniji 2,14\%, Srbiji 2,10\% i Bugarskoj 1,63\% ukupnog ulaganja. Naknada kao postotak ukupne imovine hrvatskih mirovinskih fondova u 2011. godini iznosila je oko $0,78 \%$ (eng. expense ratio) pa su tako jedino švedski, bolivijski i čileanski mirovinski fondovi bili jeftiniji od hrvatskih. Kako je navedeno, od početka 2012. naknada za upravljanje smanjena je na $0,45 \%$ pa je spomenuti expense ratio u Hrvatskoj 0,56\%. To, naravno, ne znači kako ne treba dalje težiti smanjivanju iznosa naknada.

\section{ZAKLJUČNA RAZMATRANJA}

Sva tri stupa mirovinskog osiguranja trebala bi zajedno osigurati veću socijalnu sigurnost i veću ukupnu razinu mirovina, odnosno na bolji način smanjiti rizike starosti, invalidnosti i smrti. Time se rizici osiguranja dijele na više razina i nositelja osiguranja, što bi, prema ciljevima reforme, i za korisnike mirovina i za ukupna gospodarska kretanja trebalo biti povoljnije od mirovinskog osiguranja koje ovisi samo o tekućoj uplati doprinosa i generacijskoj solidarnosti. Ulaganjem mirovinskih fon- dova trebala bi se povećati domaća štednja i investicije, što bi trebalo potaknuti razvoj tržišta kapitala, gospodarski rast i povećanje životnog standarda. Mirovinska bi reforma trebala pridonijeti modernizaciji gospodarstva, posebno financijskog sektora, no i donijeti druge pozitivne rezultate poput ublažavanja siromaštva.

Državi vječno nedostaje sredstava, pa akumulirana sredstva na osobnim računima osiguranika ponekad predstavljaju jako privlačnu »zlatnu vreću« u koju bi se lako moglo zagrabiti za trenutno pokrivanje raznovrsnih i brojnih tekućih rashoda, ali krajnji učinak takvih neželjenih intervencija u II. stupu ustvari znači implicitno povećanje javnog duga u budućnosti, jače porezno opterećenje te pojačanu ovisnost budućih umirovljenika o broju zaposlenih i trenutnom gospodarskom stanju u zemlji. Ovakve jednokratne brzoplete mjere pogotovo su opasne za zemlje s opadajućim natalitetom (poput Hrvatske) uslijed očekivanog pada broja radno aktivnih stanovnika te povećanog udjela starijeg stanovništva. Potaknuti sličnim rješenjima u bližem okruženju (posebice Mađarska i Poljska) pojedini stručnjaci, a i malobrojni donositelji odluka iz područja mirovinskog osiguranja u Hrvatskoj očigledno ponekad imaju sklonost povoditi se za brzim i nedovoljno promišljenim receptima koji jamče tek djelomično ublažavanje problema mirovinskog deficita u iznimno kratkom roku.

Jednokratni kratkoročni fiskalni učinak na taj se način pretvara u implicitni dug u budućnosti, u trenutku kada će se iz sustava međugeneracijske solidarnosti morati isplaćivati mirovine budućih umirovljenika. Kao što pretvaranje implicitnog mirovinskog duga eksplicitnim ne rješava probleme kratkotrajne fiskalne neravnoteže, što su pokazala latinsko-američka iskustva, isto vrijedi i obratno, odnosno naizgledno kratkoročno smanjivanje eksplicitnog javnog duga uslijed zamrzavanja uplata i/ili 
ukidanje kapitalizirane obvezne mirovinske štednje, srednjoročno i pogotovo dugoročno može imati vrlo nepovoljne posljedice na implicitni javni dug. Ono bi ujedno i narušilo međugeneracijsku opterećenost izdvajanjima za mirovine te bi mladi naraštaji u potpunosti snosili mirovinske rashode velikog broja umirovljenika. Zasad ne postoji nikakav izračun troškova i posljedica ukidanja drugog stupa zato što to nitko i nije izravno predložio, ali postoji vrijedno istraživanje Danijela Nestića (2018.).

Očigledno je da postoji opravdanost za opstanak izdvajanja za kapitalizirani oblik mirovinskog osiguranja (II. stup). Povrat od ulaganja je zavidan, a naknade obveznim mirovinskim fondovima razmjerno su niske s tendencijom daljnjeg smanjivanja. Moguće zamrzavanje uplata i/ili ukidanje kapitalizirane obvezne mirovinske štednje imalo bi vrlo nepovoljne gospodarske učinke, a dovelo bi i do razbijanja povjerenja u taj sustav štednje, koji se uspješno i postupno gradi više od desetljeća. Stvaranje povjerenja u bilo koji oblik javne politike je dugotrajan i naporan posao koji zahtijeva posvećenost i odlučnost svih sudionika, pogotovo korisnika, a razbijanje tog povjerenja je vrlo lako i brzo, s dugotrajnim nepovoljnim posljedicama. Zamrzavanje uplata ili ukidanje kapitalizirane obvezne mirovinske štednje samo bi nakratko ublažilo proračunski deficit, a državi bi stvorilo velike dugotrajne poteškoće u ispunjavanju obveza prema osobama koje su ostvarile mirovinska prava. Potrebno je ispraviti nelogičnosti i nepravde koje sada postoje u sustavu vezane uz dodatak na male mirovine, odnosno provesti proširenje dodatka na mirovinu na sve umirovljenike koji primaju mirovinu i iz drugoga stupa (uvođenje dodatka u visini 27 posto na iznos cijele osnovne mirovine).

Naravno, u daljnjem razvoju cjelokupnog mirovinskog sustava dobrodošle su sve analize i rasprave vezane uz podrobno djelovanje i moguće poboljšanje II. stupa jer to može biti samo na dobrobit osiguranika. Svaka nagla i nedovoljno promišljena odluka o mijenjanju njegovih osnovnih obilježja može ozbiljno ugroziti financijsku stabilnost cijelog gospodarstva, povjerenje u taj sustav i buduće mirovine hrvatskih građana. Konačno, to bi predstavljalo grubu povredu pravne sigurnosti čime bi se narušila ionako slaba vladavina prava u Hrvatskoj.

\section{LITERATURA}

Bađun, M., \& Klemenčić, I. (2011). Troškovi upravljanja institucija I. i II. stupa mirovinskog osiguranja. Newsletter, 63. Zagreb: Institut za javne financije. Dostupno na https://www.ijf.hr/upload/ files/file/newsletter/63.pdf

Barr, N. (2000). Reforming pensions: Myths, truths, and policy choices. IMF Working Paper, WP/00/139. Washington, DC: International Monetary Fund. Available at http://www.imf.org/ external/pubs/ft/wp/2000/wp00139.pdf

Bejaković, P. (2002). Evazija doprinosa za mirovinsko osiguranje. Financijska teorija i praksa, 26(1), 317-349. https://hrcak.srce.hr/5940

Bejaković, P. (2013). The importance of social transfers in reducing poverty in Croatia. Ekonomska istraživanja-Economic Research, (Special Issue 1), 103-116. https://hrcak.srce.hr/133123

Državni zavod za statistiku. (2017). Pokazatelji siromaštva i socijalne isključenosti u 2016. - konačni rezultati. Priopćenje, 14.1.1. Zagreb: Državni zavod za statistiku.

Feldstein, M. (1995a). Social security and saving: New time series evidence. National Tax Journal Working Paper No. 5054. Cambridge: National Bureau of Economic Research.

Feldstein, M. (1995b). Tax avoidance and the deadweight loss of the income tax. National Tax Journal Working Paper No. 5055. Cambridge: National Bureau of Economic Research,

Feldstein, M. (1995c). Behavioral responses to tax rates: Evidence from TRA86. American Economic Review, 85(2), 170-174. https://doi.org/10.3386/ w5000

Feldstein, M. (1995d). Would privatizing social security raise economic welfare?. National Bureau of Economic Research Working Paper No. 5281. Cambridge: National Bureau of Economic Research.

Feldstein, M. (1996). The missing piece in policy analysis: Social security reform. National $\mathrm{Bu}$ - 
reau of Economic Research Working Paper No. 5413. Cambridge: National Bureau of Economic Research.

Fultz, E., (2011). Mirovinske promjene u Mađarskoj i Poljskoj: spoznaje iz radne studije. Izlaganja na okruglim stolovima Analiza mirovinskog sustava. Zagreb: Institut za javne financije. Dostupno na http://www.ijf.hr/upload/files/file/ AMS/zbornik.pdf

Grbavac, D. (2011). Novi mirovinski sustav - izvor novih nepravdi?. Izlaganja na okruglim stolovima Analiza mirovinskog sustava. Zagreb: Institut za javne financije. Dostupno na http://www.ijf.hr/ upload/files/file/AMS/zbornik.pdf

Holzmann, R., Hinz, R. (2005). Old-age income support in the Twenty-first century: An International perspective on pension systems and reform. Washington, DC: The World Bank. Available at http://siteresources.worldbank.org/ INTPENSIONS/Resources/Old_Age_Income_ Support_Complete.pdf

Hrvatski zavod za mirovinsko osiguranje. (2018). Statističke informacije Hrvatskog zavoda za mirovinsko osiguranje, 16(1). Dostupno na http:// www.mirovinsko.hr/UserDocsImages/ publikacije/statisticke_informacije/2018/Statisticke_informacijeHZMOa_1_2018_travanj2018.pdf

International Federation of Pension Fund Administrators. (2016). Contributions of the individually-funded pension systems and their advantages over the public PAYGo Programs. Pension Note No. 11. Available at http://www.fiapinternacional. org/wp-content/uploads/2016/01/Pensions-Note-No-11_v12.12.2016.pdf_

Ministarstvo zdravstva i socijalne skrbi. (2007). Zajednički memorandum o socijalnom uključivanju Republike Hrvatske. Zagreb: Ministarstvo zdravstva i socijalne skrbi.

Müller, K. (2002). Strukturalne mirovinske reforme u tranzicijskim zemljama: politički sudionici i uloga države. Financijska teorija i praksa, 26(2), 387-404. https://hrcak.srce.hr/5884

Nestić, D. (2018). Mišljenje o prijedlogu mirovinske reforme i rješavanju problema nižih mirovina umirovljenika osiguranih u oba obvezna mirovinska stupa, Zagreb: Ekonomski institut. Dostupno na https://www.eizg.hr/danijel-nestic-misljenje-o-prijedlogu-mirovinske-reforme-i-rjesavanju-problema-nizih-mirovina-umirovljenika-osiguranih-u-oba-obvezna-mirovinska-stupa/4209

Nestić, D., \& Tomić, I. (2012). Primjerenost mirovina u Hrvatskoj: što mogu očekivati budući umirovljenici?. Privredna kretanja i ekonomska politika, 22(130), 61-100. https://hrcak.srce.hr/83125
Obvezni mirovinski fond PBZ Croatia. (2018). Izvještaj o radu obveznih mirovinskih fondova kojima upravlja PBZ Croatia osiguranje d.d. za upravljanje obveznim mirovinskim fondovima za 2017. godinu. Dostupno na https://vlada. gov.hr/UserDocsImages//Sjednice/2018/04\%20 travnja/93\%20sjednica $\% 20 \mathrm{VRH} / / 93 \% 20-\% 20$ 8.9.pdf

Organisation for Economic Co-operation and Development. (2014). OECD Pensions Outlook 2014. Paris: OECD Publishing. https://doi.or$\mathrm{g} / 10.1787 / 9789264222687$-en

Organisation for Economic Co-operation and Development. (2016). Pension Markets in Focus, 2016 edition. Paris: OECD. Available at http:// www.oecd.org/pensions/private-pensions/pensionmarketsinfocus.htm

Orszag, P. R., \& Stiglitz, J. E. (2001). Rethinking pension reform: Ten myths about social security systems. In R. Holzmann \& J. E. Stiglitz (Eds.), New Ideas About Old Age Security: Towards Sustainable Pension Systems in the $21^{\text {st }}$ Century (pp. 24-28). Washington, DC: The World Bank.

Pan, S. (2011). Intragenerational risk sharing and redistribution under unfunded pension systems: An experimental study. Tilburg: Department of Economics, Tilburg University. Available at https://www.netspar.nl/en/publication/intragenerational-risk-sharing-and-redistribution-under-unfunded-pension-systems-an-experimental-study/

Potočnjak, Ž., \& Vukorepa, I. (2018). Drugi mirovinski stup: prijepori i moguća poboljšanja. U P. Miladin \& M. Giunio (ur.), Zbornik 56. susreta pravnika (pp. 231-271). Zagreb: Hrvatski savez udruga pravnika u gospodarstvu. Dostupno na http://bib.irb.hr/datoteka/938890.II._MS_prijepori_i_mogua_poboljanja_Potonjak_Vukorepa_2018_objavljeno.pdf

Raiffeisen istraživanja. (2014). Prošlost, sadašnjost i budućnost mirovinskog sustava $u$ RH. Zagreb: Raiffeisenbank Austria d.d.

Rosen, S. H. (1999). Javne financije. Zagreb: Institut za javne financije.

Strategija razvitka Republike Hrvatske "Hrvatska u 21. stoljeću" - Strategija razvitka mirovinskog sustava i sustava socijalne skrbi. Narodne novine, br. 97/2003.

Šućur, Z. (2005). Siromaštvo i socijalni transferi u Hrvatskoj. Financijska teorija i praksa, 29(1), 37-58. https://hrcak.srce.hr/5712

Štimac, D. (2011). Obvezni mirovinski fondovi u Hrvatskoj - prvih 10 godina. Izlaganja na okruglim stolovima Analiza mirovinskog sustava. Zagreb: 
Institut za javne financije. Dostupno na http:// www.ijf.hr/upload/files/file/AMS/zbornik.pdf

Udruženje mirovinskih fondova. (2016). Izvještajo radu obveznih mirovinskih fondova za 2015. godinu. Zagreb: Udruženje mirovinskih fondova. Dostupno na www.sabor.hr/ fgs.axd?id=45222

Udruženje mirovinskih fondova. (2018). Izvještaj o radu obveznih mirovinskih fondova za 2017. godinu. Zagreb: Udruženje mirovinskih fondova. Dostupno na www.sabor.hr/ fgs.axd?id=52916

Urban, I., Munđar, D., \& Bejaković, P. (2011). Mirovinski sustav i preraspodjela dohotka. Zagreb: Institut za javne financije. Dostupno na http://www.ijf.hr/upload/files/file/prezentacije/ MIROVINSKI_SUSTAV_I_PRERASPODJELA_DOHOTK.pdf

Vukorepa, I. (2011). Kapitalno financirani mirovinski sustavi kao čimbenici socijalne sigurnosti (doktorska disertacija). Zagreb: Sveučilište u Zagrebu, Pravni fakultet.

Vukorepa, I. (2015). Lost between sustainability and adequacy: Critical analysis of the Croatian pension system's parametric reform. Revija za socijalnu politiku, 22(3), 279-308. https://doi. org/10.3935/rsp.v22i3.1307

Vukorepa, I. (2017). ESPN Thematic Report: Contribution to the 2018 Pension Adequacy Report, Croatia. Brussels: Directorate-General for Employment, Social Affairs and Inclusion. Available at https://bib.irb.hr/datoteka/940686. HR_ESPN_TR1_2017-18_PAR_20171209_FINAL_clean.pdf

World Bank. (2011). Croatia - Policy options for further pension system reform. Washington, DC: World Bank. Available at http://documents.worldbank.org/curated/en/ 623691468262449583/ Croatia-Policy-options-for-further-pension-system-reform

Zuber, M. (2010). Mogućnosti poboljšanja socioekonomskih i fiskalnih učinaka sustava obveznog mirovinskog osiguranja u Hrvatskoj (doktorska disertacija). Rijeka: Sveučilište u Rijeci, Ekonomski fakultet. 


\title{
Summary
}

\section{THE CAUSES OF PROBLEMS IN THE PUBLIC PENSION SYSTEM AND REASONS WHY FUNDED PENSION INSURANCE SHOULD BE PRESERVED IN CROATIA}

\author{
Predrag Bejaković \\ Institute of Public Finance \\ Zagreb, Croatia
}

The pension system has different demanding tasks that may sometimes be mutually in conflict. Despite the apparent improvement in the financial position of older people, the intergenerational solidarity system also has some adverse effects. It could distort labour supply and forms of compensation, increase the loss of dead weight effect of social insurance contributions, exaggerate redistribution in the system and create long-term unsustainable pressure on public finances. Therefore, a pension reform was implemented in Croatia and a funded system with personal accounts was introduced. Possible freezing or cancellation of the funded system would have highly unfavourable economic effects and would lead to a breakdown of trust in this savings system. It would only briefly mitigate the budget deficit, while simultaneously it would create great long-lasting difficulties for the government in meeting the obligations towards persons who had acquired pension rights. The purpose of this text is to clarify the importance of preserving compulsory funded (capitalized) pension insurance (the second pillar) in Croatia. The paper explains the most significant features of the funded pension insurance and offers possibilities for improvements.

Key words: pension system, pension rights, funded pension insurance, social security, Croatia. 